\title{
Digitalization of communications with applicants as an innovative approach in modern higher education
}

\author{
Irina Baranova ${ }^{1, *}$, Marina Gapon ${ }^{1}$, and Elena Golova ${ }^{1}$ \\ ${ }^{1}$ FSBEI of HE Omsk State Agrarian University named after P.A. Stolypin, 1, Institutskaya square, Omsk, 644008, Russia
}

\begin{abstract}
In modern complex conditions, characterized by an unstable situation caused by a global pandemic, the acceleration of digitalization processes in all spheres of life, innovative software products that help users to receive complete and up-to-date information on emerging issues are becoming more and more important. Usually even such fateful decisions as the choice of a future profession and educational institution are made on the basis of data collection in mobile applications. In this regard, research in the field of digitalization of communications between universities, applicants and other stakeholders at this stage of development of Russian educational services is quite important. This paper is devoted to the study of the issue of the establishment of mutually beneficial links between applicants and Russian universities. The authors propose the implementation of an organizational project in order to create a multifunctional mobile application "Applicant" aimed to provide target groups of users with versatile, up-to-date information about the state of university education market. The project describes in detail and justifies such points as the formation of a team, the functions and competencies of its members, the main stages and environment of implementation, the implementation schedule, product and educational results.
\end{abstract}

\section{Introduction}

Modern conditions caused by the ongoing digitalization of economy, difficulties in the educational sphere that have appeared as a result of the Covid-19 pandemic, literally force educational organizations to look for new approaches to management. At the same time, the processes of the introduction of innovative solutions are observed in all areas: educational, scientific, pedagogic activities, etc.

A special place in the functioning of universities is occupied by work with applicants, which has undergone significant changes over the past year. Obviously, the further fate of educational institutions will depend on how effectively the enrollment campaign will take place. Therefore, the administration of universities is interested in the use of innovative methods in order to attract future students.

On the other hand, applicants also faced great difficulties. For many of them it was impossible to get offline information on the application. If earlier the use of online services was considered as one of the options to find information about universities, then in 2020 this state of affairs turned out to be the only possible one. At the same time, existing sites and mobile applications on this topic are characterized by scarcity and irrelevant information.

These circumstances indicate that there is a need to improve work with applicants both in their interests and in the interests of universities.

The studies of the digitalization of the attraction of students have been carried out over the past years quite actively by many Russian scientists. Thus, among the works highlighting these aspects of the education sector, it is possible to note the works of I.S. Zamulin, A.A.

Golubnichiy, N.D. Artyomov, P.G. Petrushi, D.K. Kozlova, V.Yu. Skaliukha, E.V. Nuzhnov and others [13]. In addition, it is necessary to note the activity of developers of various software products, one way or another related to the automation of work with applicants to higher educational institutions. At the same time, the overwhelming majority of studies are of a local nature, characterized by the reference of the research object to a specific university. A few works concern the digitalization of communications with applicants in terms of the creation of automated information programs for applicants and students.

In general, the analysis of the literature shows that there are gaps in the study of issues of digitalization of university activities in relation to those students who plan to get higher education.

In the context of the studied topic, special attention is paid to the review of sources of the use of innovative approaches in higher education. In recent years, Russian scientists have been studying innovations in higher education from various points of view, paying attention to the problems of distance learning, the integration of traditions and innovations, the use of innovative methods in the educational process, etc. Among the Russian researchers of this topic, we can mention O.A. Ivanova, F.U. Zairova, A.S. Gnennaya, S.V. Vivatenko, A.S. Veremchuk, E.A. Leushkina and others [4-7].

Special emphasis needs to be given to the authors specializing in the study of the "innovation-universityapplicant" system. This list includes V.N. Kartashova,

Corresponding author: iv.baranova@omgau.org 
M.A. Lapina, M.P. Prokhorova, S.V. Bulganina, P.D. Zimnikova. Lektorova Yu.Yu. and others [8-11].

Thus, there is a high level of interest of Russian scientists in the research of the problems of the introduction of innovative approaches in the work with university applicants.

The purpose of the study is to deepen the theoretical and methodological approaches to the digitalization of communication processes between applicants and higher educational institutions, taking into account the use of modern innovative approaches.

The scientific novelty of the research is in the project proposed by the authors to improve communication with applicants in the modern digital environment.

The theoretical and practical importance of the study is in the improvement of the efficiency of higher education institutions with applicants, as well as expansion of the opportunities for applicants to search for information about the educational services market through the use of modern innovative approaches.

\section{Materials and Methods}

During the research on this topic, general scientific methods were used, such as analysis, synthesis, induction, deduction and comparison.

In the course of the study, the authors paid due attention to the search for information in the Internet that would help applicants to get a complete picture of the opportunities available on the educational services market for an informed choice of the future university (USE scores, education fees, university rating) [12].

The analysis of the data regarding the available mobile applications in modern search databases shows the presence of certain mobile applications, such as: «Russian universities », « Do the right thing », « Russian entrant $»$, etc.

The disadvantages of these applications are their disunity, independence from each other, lack of communication with higher educational institutions and authorities (ministries, departments). Each of the applications provides fragmentary, incomplete and often irrelevant information for applicants.

That is, today there is no single database that would reflect all the data requested by applicants.

\section{Results and Discussion}

In order to fill the information niche that has appeared on the Russian market of university services in terms of the establishment of a digital environment for communication between applicants and universities, the authors propose to create an organizational project. The essence of the project (product result): development of a multifunctional mobile application for applicants, universities of the Russian Federation and other stakeholders (students, graduates of universities, organizations (employers)) in order to form a single information space between its participants.
Stakeholders who are interested in the use of the project result:

1. Project users: applicants, university students, university graduates, university staff, organizations (employers).

2. Customers of the project: ministries (departments), higher educational institutions.

3. Investors of the project: organizations interested in results (ministries, universities, employing organizations, other investors).

Table 1 shows the composition of the main tabs of a multifunctional mobile application, as well as the functions of these tabs.

Table 1. Main tabs of the multifunctional mobile application (MMA)

\begin{tabular}{|c|c|}
\hline $\begin{array}{c}\text { Application } \\
\text { tabs }\end{array}$ & $\begin{array}{l}\text { Functions performed by the } \\
\text { application }\end{array}$ \\
\hline $\begin{array}{l}\text { user personal } \\
\text { account }\end{array}$ & $\begin{array}{l}\text { personal data and information about } \\
\text { the user of the mobile application }\end{array}$ \\
\hline $\begin{array}{c}\text { higher } \\
\text { educational } \\
\text { institutions } \\
\text { (university) }\end{array}$ & $\begin{array}{l}\text { informing users about universities in } \\
\text { various cities of the Russian } \\
\text { Federation (university rating, areas } \\
\text { of training, forms of study, number } \\
\text { of budget places, education fees, } \\
\text { exam passing score, university } \\
\text { vacancies, etc.), university } \\
\text { enrollment application }\end{array}$ \\
\hline $\begin{array}{l}\text { applicant (school } \\
\text { student) }\end{array}$ & $\begin{array}{l}\text { informing users about the number of } \\
\text { registered applicants (school } \\
\text { students) in the application database, } \\
\text { places of their study, USEs, priority } \\
\text { areas for enrollment, etc. university } \\
\text { enrollment application }\end{array}$ \\
\hline student & $\begin{array}{l}\text { informing users about university } \\
\text { students, forming a bank of } \\
\text { vacancies for students, generating } \\
\text { information about outstanding } \\
\text { students, student schedule }\end{array}$ \\
\hline $\begin{array}{l}\text { university } \\
\text { graduate }\end{array}$ & $\begin{array}{l}\text { informing users about university } \\
\text { graduates, including outstanding } \\
\text { (successful) ones, the formation of } \\
\text { monitoring the employment of } \\
\text { graduates, a bank of vacancies for } \\
\text { graduates in the areas of training }\end{array}$ \\
\hline $\begin{array}{l}\text { organizations } \\
\text { (employers) }\end{array}$ & $\begin{array}{l}\text { informing users about organizations, } \\
\text { employers registered in the database, } \\
\text { forming a bank of vacancies } \\
\text { according to the availability of } \\
\text { vacancies, informing graduate } \\
\text { students about conditions of } \\
\text { internship, practical training }\end{array}$ \\
\hline
\end{tabular}

Feedback from users of the developed multifunctional application is extremely important in the creation of this project. We need to figure out how the application works, what the inconvenience of tabs is, or what additional information may be needed. That is, it will be necessary to take into account the user experience as a result of the operation of this application. 
Here we present the main stages of the project and the main tasks solved at each stage of the project.

The $1^{\text {st }}$ stage: Problem statement

Tasks:

-To determine the existing problems (lack of relevant information about universities and their ratings, the number of budget places, education fees, data on areas of training, dormitories, applicants, students, the number of employed students, etc.).

-To conduct a survey, questioning schoolchildren, applicants, students, university staff, employers about what they want to see in the mobile application being developed.

-To monitor available search databases, applications (lack of a single database for the chain applicant (student) - university-student-graduate - universityemployer).

The $2^{\text {nd }}$ stage: Statement of a goal, hypothesis (to develop a multifunctional mobile application)

Tasks: What problems can MMA solve?

-To establish communication with ministries (universities) on the formation of the terms of reference for the project.

\section{Tasks:}

The $3^{\text {rd }}$ stage: Determination of the main tasks

-To develop a work plan. (The project participants are divided into groups. Each group forms information in the context of its area of responsibility (by tabs), according to the identified problems, based on the results of the analysis of questionnaires and surveys.

The $4^{\text {th }}$ stage: Creation of a mobile application

Tasks: Basic work according to plan.

- To learn to communicate in a team. Training of project participants to form the required competencies

The $5^{\text {th }}$ stage: Project results

Tasks: -To test the developed mobile application

- To formulate conclusions

The 6th stage: Introduction

Tasks: -To distribute, to carry out an advertising campaign

The $7^{\text {th }}$ stage: Opeartion

Tasks:-To check feedback from users of the mobile application

- To eliminate comments and take into account user experience

Table 2 presents the approximate timetable for the implementation of the project.

The important aspect of project development is the description of the environment for its implementation. Thus, the authors propose the following elements of the environment:

- The equipment for project implementation: separate classes, computers with technical equipment (printer, copying machine, scanner), tables, chairs, whiteboards (interactive).
- External participants: experts - technical consultants, programmers, administrative and management personnel of higher education institutions.

Table 2. Approximate timetable for the implementation

\begin{tabular}{|c|c|c|c|c|c|c|c|c|c|c|c|}
\hline \multirow[t]{2}{*}{ Stage } & \multicolumn{11}{|c|}{$\begin{array}{l}\text { Academic year (months from September } \\
\text { to July) }\end{array}$} \\
\hline & 09 & 10 & 11 & 12 & 01 & 02 & 03 & 04 & 05 & 06 & 0 \\
\hline I Problem statement & + & + & & & & & & & & & \\
\hline $\begin{array}{l}\text { II Statement of a goal, } \\
\text { hypothesis (to develop a } \\
\text { multifunctional mobile } \\
\text { application) }\end{array}$ & & + & + & & & & & & & & \\
\hline $\begin{array}{l}\text { III Statement of main } \\
\text { problems }\end{array}$ & & & + & + & & & & & & & \\
\hline $\begin{array}{l}\text { IV Determination of the } \\
\text { main tasks }\end{array}$ & & & & & + & + & & & & & \\
\hline V Project results & & & & & & & + & & & & \\
\hline VI Introduction & & & & & & & & + & & & \\
\hline VII Operation & & & & & & & & & + & + & + \\
\hline
\end{tabular}

A higher educational institution is the platform for the implementation of the project.

The requirements for the project participants: the number of participants is 30 people (approximately), 10 are school students - applicants, 10 students of secondary courses, 10 graduates (or graduate students).

Since school students and students are included in the team, the educational result obtained as a result of the project is predicted.

Stage I. Problem statement.

Educational results:

$\checkmark \quad$ Understanding of the problem field (lack of real information about universities and their ratings, insufficient information in the available applications about the availability of budget places, hostels, education fees, etc.) by applicants (school students) and students;

$\checkmark$ Formation of skills when interacting with experts (the role of an expert is played by the administrative and managerial staff of universities, programmers, employers);

$\checkmark$ Applicants and students at this stage studied various ways to search the data on the selected problem (monitoring of modern Internet portals, programs and search databases as Play Market, Google Play, Appstore, Yandex.Store, AndroidPIT, Getjar, etc.);

Values : sociability, initiative, independence.

Stage II. Purpose and tasks.

Educational results:

$\checkmark$ Applicants and students learned to master some methods of work (goal setting, assignment of tasks);

Stage III. Project realization

Educational results:

$\checkmark$ Development of communication links between applicants (school students) and students: the formation of a constructive dialogue, 
acceptance and respect of cultural and professional differences between each other

Stage IV. Presentation of results

\section{Educational results:}

$\checkmark$ Skills and experience of public performance;

$\checkmark$ Scientific article;

$\checkmark$ Report;

Stage V. Reflection

Educational results:

$\checkmark$ Understanding by applicants and students that they might have not analyzed all the search bases;

Table 3. Project participants, their main functions and competencies

\begin{tabular}{|c|c|c|c|}
\hline $\begin{array}{l}\text { Project team } \\
\text { composition }\end{array}$ & $\begin{array}{c}\text { Roles (functions) of } \\
\text { participants in the team }\end{array}$ & $\begin{array}{l}\text { Knowledge, competence } \\
\text { and skills }\end{array}$ & $\begin{array}{c}\text { Work } \\
\text { experience }\end{array}$ \\
\hline $\begin{array}{l}\text { Applicants (school } \\
\text { students) }\end{array}$ & $\begin{array}{l}\text { Analysis of } \begin{array}{r}\text { available } \\
\text { databases, }\end{array} \\
\text { problem } \\
\text { solution, tab development }\end{array}$ & $\begin{array}{l}\text { Knowledge of the main } \\
\text { search bases, skills }\end{array}$ & Absent \\
\hline First year students & $\begin{array}{l}\text { Analysis of } \begin{array}{l}\text { available } \\
\text { databases, } \\
\text { solution, tab development }\end{array} \\
\end{array}$ & $\begin{array}{l}\text { Knowledge of the main } \\
\text { search bases, skills }\end{array}$ & Part-time \\
\hline Second students & $\begin{array}{lr}\begin{array}{l}\text { Analysis of } \\
\text { databases, }\end{array} & \begin{array}{l}\text { available } \\
\text { problem }\end{array} \\
\text { solution, tab development }\end{array}$ & $\begin{array}{l}\text { Knowledge of the main } \\
\text { search bases, skills; ability } \\
\text { to pose and solve problems }\end{array}$ & Part-time \\
\hline Graduate students & $\begin{array}{l}\text { Analysis of } \\
\begin{array}{l}\text { available } \\
\text { databases, }\end{array} \\
\text { solution, tab development }\end{array}$ & $\begin{array}{l}\text { Knowledge of the main } \\
\text { search bases, skills; ability } \\
\text { to pose and solve problems }\end{array}$ & Part-time \\
\hline $\begin{array}{l}\text { Employees of higher } \\
\text { education institutions } \\
\text { (administrative and } \\
\text { management personnel) }\end{array}$ & $\begin{array}{l}\text { Compensation of the lack of } \\
\text { knowledge and skills of the } \\
\text { team, assistance in the } \\
\text { narrow specialization of the } \\
\text { issue }\end{array}$ & $\begin{array}{l}\text { Scientific and professional } \\
\text { knowledge and competence }\end{array}$ & Present \\
\hline $\begin{array}{l}\text { Employees of higher } \\
\text { educational institutions } \\
\text { (employees of the } \\
\text { selection committee, } \\
\text { employment } \\
\text { department, teachers) }\end{array}$ & $\begin{array}{l}\text { Compensation of the lack of } \\
\text { knowledge and skills of the } \\
\text { team, assistance in the } \\
\text { narrow specialization of the } \\
\text { issue }\end{array}$ & $\begin{array}{l}\text { Scientific and professional } \\
\text { knowledge and competence }\end{array}$ & Present \\
\hline $\begin{array}{l}\text { Representatives of } \\
\text { organizations } \\
\text { (employers) }\end{array}$ & $\begin{array}{l}\text { Assistance in the narrow } \\
\text { specialization of the issue }\end{array}$ & $\begin{array}{l}\text { Scientific and professional } \\
\text { knowledge and competence }\end{array}$ & Present \\
\hline Laboratory assistant & $\begin{array}{l}\text { Maintenance of the } \\
\text { environment, provision of } \\
\text { the safety of work and the } \\
\text { availability of equipment, } \\
\text { and operation of the } \\
\text { equipment }\end{array}$ & $\begin{array}{l}\text { Skills of working with } \\
\text { equipment }\end{array}$ & Present \\
\hline Experts (programmers) & $\begin{array}{l}\text { Assistance in the narrow } \\
\text { specialization of the issue, } \\
\text { programming a mobile } \\
\text { application }\end{array}$ & $\begin{array}{l}\text { Skills of working with } \\
\text { professional equipment } \\
\text { and specialized software }\end{array}$ & Present \\
\hline $\begin{array}{l}\text { Representative of the } \\
\text { ministry (department) }\end{array}$ & $\begin{array}{l}\text { Is the customer of the } \\
\text { project, pays for the project, } \\
\text { prepares the terms of } \\
\text { reference }\end{array}$ & $\begin{array}{l}\text { Understanding the } \\
\text { importance of the project } \\
\text { in education }\end{array}$ & Present \\
\hline Tutor & $\begin{array}{l}\text { Is engaged in educational } \\
\text { support, solves educational }\end{array}$ & $\begin{array}{l}\text { General awareness and } \\
\text { understanding of the topic }\end{array}$ & Present \\
\hline
\end{tabular}

$\checkmark \quad$ Applicants and students can evaluate the results of their own work and form activities to improve the efficiency of the proposed product

Table 3 presents the characteristics of the project team. The composition of the project team, the main functions of the participants and competencies are determined. 


\begin{tabular}{|l|l|l|c|}
\hline & problems & $\begin{array}{l}\text { of the project, the ability to } \\
\text { build communications in a } \\
\text { team, assistance in self- } \\
\text { determination for project } \\
\text { participants pedagogical } \\
\text { competencies, etc. }\end{array}$ \\
\hline Curator & $\begin{array}{l}\text { Organizes all participants, } \\
\text { ensures the product result } \\
\text { of the project }\end{array}$ & $\begin{array}{l}\text { Basic scientific and } \\
\text { professional knowledge, } \\
\text { organizational Present } \\
\text { management, design, } \\
\text { pedagogical competence, } \\
\text { etc. }\end{array}$ \\
\hline $\begin{array}{l}\text { Stakeholders (mobile } \\
\text { app users, customers, } \\
\text { investors) }\end{array}$ & $\begin{array}{l}\text { Is interested in the result of } \\
\text { the project, provide } \\
\text { knowledge, information, } \\
\text { money }\end{array}$ & $\begin{array}{l}\text { Skills of the use of a mobile } \\
\text { application; skills in project } \\
\text { implementation } \\
\text { making a profit from it }\end{array}$ & Present \\
\hline
\end{tabular}

Thus, the proposed project includes the main particular elements. Every element is worked out in

detail and is ready for testing. Free MySQL DBMS, an open source relational database management system [13] can be chosen as a tool for the creation of a database of the system. The detailed development of this component of the project should be performed by programmers.

\section{Conclusion}

The implementation of the project results will solve the following problems:

- the lack of real information for applicants about the higher educational institutions of the Russian Federation according to the necessary search criteria (requests);

- the lack of information on the ratings of higher educational institutions;

-the impromptness, immobility when submitting documents for enrollment to a higher educational institution;

- the unemployment of students (graduates) of higher educational institutions (part-time / full-time employment), failure to provide a place for internship and practical training;

- the lack of information about outstanding graduates;

- the lack of information space for communication links in the chain «applicant (student) - universitystudent-graduate - university-employer».

Taking into that Internet commerce has such undoubted advantages as high speed, low cost, which allows increasing the efficiency of transactions [13], it is possible to predict the continued growth of demand for the purchase of goods and services through the worldwide network, including the demand for educational services, or at least, the search for information on these services.

The authors believe that the implementation of the project at the initial stage is possible in the form of a pilot based on one of the Russian regions. If positive results are obtained, it is possible to carry out certain adjustments and expand the scale to the level of the educational services market throughout the entire country.

\section{References}

1. I.S. Zamulin, A.A. Golubnichy, N. D. Artyomova, Scientific and technical bulletin of the Volga region, 9, (2020)

2. P.G. Petrusha, D.K. Kozlova, Economics and Entrepreneurship, 10 (123), (2020)

3. V.Yu. Skaliukh, E.V. Nuzhnov, Proceedings of the International Scientific and Technical Congress Intelligent Systems and Information Technologies - 2019" (IS \& IT-2019, IS \& IT'19), Department Intelligent Information Subsystem for Applicant Support, (2019)

4. O.A. Ivanova, Scientific Research and Modern Education, (2018)

5. F.U. Zairova, Vectors of modern science, 1 (3), (2016)

6. A.S. Gnennaya, Priority models of social development in the era of modernization: economic, social, philosophical, political, legal aspects (2016)

7. S.V. Vivatenko, A.S. Veremchuk, Science and Education in the 21st Century: Theory, Methodology, Practice (2019)

8. V.N. Kartashova, Siberian teacher, 3 (118), (2018)

9. M.A. Lapina, Energy saving and innovative technologies in the fuel and energy complex, (2018)

10. M.P. Prokhorova, S.V. Bulganina, Bulletin of Nizhnevartovsk State University, 3, (2017)

11. P.D. Zimnikova, Yu. Yu. Lektorova, Translation, advertising and PR in modern communication, $\mathbf{1}$, (2019)

12. Z. Uvaleyeva, D. Mukhiyayeva, I. Baranova, M. Valieva, O. Kopylova, Journal of Entrepreneurship Education, 22, (2019)

13. 13.I.Kh. Gizzatov, A.A. Zlobina, M.A. Senilov, Society, 4 (19), (2020)

14. E.E. Golova, I.V. Baranova, Basic Research, 11, (2020) 